\title{
Honesty Education For Children From a Very Early Age: An Islamic Perspective On Psychology
}

\author{
Adi Heryadi ${ }^{1}$, Subandi ${ }^{2}$ \\ ${ }^{1}$ Universitas Jenderal Achmad Yani Yogyakarta, ${ }^{2}$ Universitas Gadjah Mada Yogyakarta \\ Corresponding Email: adiheryadi16@gmail.com
}

\begin{abstract}
The phenomena of corruption, collusion, and nepotism in Indonesia that are increasingly prevalent have made deep works for us as a nation. We can see the bad behavior of corruption, starting from the suboptimal quality of development results to the increasingly visible impact between the rich and the poor. People's dissatisfaction with the spectacle of corruption trials and terrible examples set by the nation's leaders has a psychological effect on the next generation. According to (Suud \& Subandi, 2017), one of the repercussions of dishonesty is corruption. From the perspective of Islamic psychology, this study tries to answer research issues concerning what and how to undertake moral education for children. A library research or literature review is used in this study, as well as a non-interactive method called document analysis. Researchers consult a variety of sources, including documents, books, websites, study findings, and expert opinions, that are relevant to the research issue. The findings of this study show that, according to Islamic psychology, honesty education for children is a type of moral character education that teaches children aged 0 to 6 years how to coordinate their hearts and brains through words and actions. They always say that the Qur'an and Hadith are the most reliable guides. Furthermore, the stages of children's integrity character education discovered in Islamic psychology are the conception period, the first three years, and the 46th year, which are key moments in integrity character education. That will be in 46 years. The basic foundations for this performance are Surah an-Nahl: 78 and Surah an-Nisa: 5.
\end{abstract}

Keywords: Honesty, Early Childhood Education, Anti-Corruption Education, Islamic psychology

\begin{tabular}{|c|c|c|c|c|}
\hline Submission & Review Process & Revised & Accepted & Published \\
\hline October 10, 2021 & $\begin{array}{c}\text { October 28, 2021- } \\
\text { December 10, 2021 }\end{array}$ & December 14, 2021 & December 14, 2021 & December 29, 2021 \\
\hline
\end{tabular}

\section{Introduction}

The phenomenon of corruption, collusion, and nepotism is a concern for us as a nation. The poor quality of development results, uneven development results, and the position of our nation in the international arena are the impacts that we feel from bad governance practices. People's dissatisfaction with the spectacle of corruption and negative examples set by this country's leaders has a psychological impact on the next generation. Corruption is one of the repercussions of dishonesty, according to Suud \& Subandi (2017). According to Heryadi \& Abd. Madjid (2021), the Indonesian Corruption Watch Exposure in early 2021 on Indonesia's
Corruption Perception Index (CPI) in 2020 certainly surprised us all, Indonesia was at 37 or decreased by 3 points from the 2019 GPA score. This year, Indonesia scored 37 points, three points lower than the IPK score from the previous year. Out of 180 countries evaluated, Indonesia's GPA ranges from 85 to 102 . The Corruption Perception Index ranges from 0 to 100 , with 0 being the most corrupt and 100 being the cleanest. These international organizations' target indicators include economics and investment, the application of law and politics, and democracy. Furthermore, according to Heryadi \& Abd. Madjid (2021), our standing as a country of concern will not prevent us from stagnating. 
Our education must contribute to the development of an anti-corruption generation, which will assist this country gain favor in the eyes of the international community as citizens.

Anti-corruption principles (honesty,
caring, independence, discipline, responsibility, hard work, simplicity, courage, and justice) that stem from within the individual, according to the KPK (www.aclc.kpk.ac.id). According to (Lestari, 2018), anti-corruption education is a longterm investment in preventing corruption. We shall equip the nation's next generation to lead a country with integrity and integrity in the future through anti-corruption education. According to (Lestari, 2018), anti-corruption education must begin early because the success or failure of subsequent educational stages is determined by early childhood education. Anti-corruption education, according to Heryadi et al (2020), is an effort to instill nine (9) anti-corruption values, known as character education, in children from an early age, including honesty, caring, independence, discipline, responsibility, and hard work, as well as simplicity, courage, and justice. More comprehensive media planning and use close to the millennial generation can start from the fifth and sixth grades of elementary school and mature from junior high school.

The author concludes from the above description that today's rampant corruption requires our contribution as educators to strengthen anti-corruption education or character, as one of the impacts of rampant corruption, as stated by Suud \& Subandi (2017), and to honestly educate current behavior. Be the focus of attention for this investigation. This study will try to explain Islamic psychology research questions as to what and how to implement honesty education in childhood. Also, this research concentrates on early childhood education, and the author says that this study is necessary because the perspective which will be used to answer the research questions is moral education in early childhood from such an Islamic psychology perspective.

\section{Research Methods}

Library research is being used in the study. The key data sources in this research are book documents, websites, research results, or expert opinions relevant to the research topic. The data obtained is then analyzed using content analysis or content analysis to come to conclusions on the issues posed, as to what and how early childhood education is characterized in Islamic psychology.

\section{Results and Discussion \\ Programs of early childhood education}

Early Childhood Education (PAUD) is a stage for 46-year-old children who are guided to face a higher level and go through these stages, according to Agustina \& Kurniawan (2019). It also provides educational stimulation which promotes physical and mental development. Children are well prepared for more education, and formal, informal, and informal education is provided. Group games and playgrounds are examples of this kind of education. The cultivation of moral values through kindergarten education is a very important aspect of the attention to education which must be given at an early age. It is hoped that through integrating value and childhood moral education, kids will be able to discriminate between good and evil, good and evil, and apply these differences in actual situations at a later stage of development. It affects whether the child is recognized by the surrounding community in terms of social interaction. Early childhood education, and according to Saputra (2018), is tutoring work for children up until the age of six years old 
by providing educational stimuli to assist physical and mental growth and development so that children are prepared to complete their studies. When a baby is born, he or she begins his learning career. To become a normal and healthy child, it is also necessary to introduce people, sounds, and objects to the baby, and also invite him to joke and talk. According to the learning method, the child's personality as an adult is usually determined from birth to six years.

Early Childhood Education (PAUD) is a kind of guidance for children from birth to the age of six years old that provides educational stimulation development, according to Law Number 20 of 2003 about the National Education System, article 1 number 14. Early childhood education (PAUD) is a level of education before primary education and prepares children physically and spiritually to continue their education. A task for children ages ranging from newborn to six years. It was all about helping the body with education. To prepare children for higher education, children need stimulation and also spiritual growth and development.

\section{Islamic Psychology}

Malik Badri is a pioneer of Islamic psychology. Malik B Badri, an African national psychologist, published "The Dilemma of Muslim Psychologists" in 1979. This book was a concise overview of Western psychology which sparked an interest in Islamic psychology. Psychological thought under Islam This movement began in Indonesia in the 1990s, and its impact grew better at the beginning of the third millennium. Some major conferences were held, and publications were published to start on. Zaharudin went on to explain that Islamic psychology failed to change after science was Muslims, mentioning the works of Ismail Raji al-Faruqi and Syed Muhammad Naquib al-
Attas, who have used the Qur'an and Hadith as a source of scientific development. According to (Zaharuddin, 2017), developing Islamic psychology combines scriptural, philosophical, and Sufism (Sufi) methods, and also practical and idealistic methods. Second, attraction, acceptance, and release will be the first phases of Islamic psychology's development. Third, the essence of Islamic psychology, according to Malik Badri (Malik Badri), is to work hard to formulate a system of reason based on the study of the Qur'an and As-Sunnah, and to reject out concepts that violate Islamic ideology.

According to Subandi (2010), Islamic psychology is a new thought among Muslim psychologists who are trying to develop concepts originating from Islam, so this teaching has been going on for a long time, the momentum that must be considered a systematic start is since Malik Badri published his book "The Dilemma of Muslim Psychologists."

Islamic psychology, according to Aryani (2018), is the science of humans. Its philosophy, theory, methodology, and methods are all based on Islamic sources from history. Islamic psychology is a style of psychology that is based on the human image. The study of Islamic teachings is the uniqueness and pattern of human behavior which is expressed as an experience, interacting with oneself, the surrounding environment, and the spiritual realm, to improve mental health and religious quality.

\section{Honesty}

According to Suud, M et al. (2020), honesty is defined as the consistency of words and deeds, the consistency of words and facts, or the consistency of actions with relevant law. This consistency translates into honesty, both in words and deeds, as well as regulations that are consistently adhered to. Lying is the polar opposite of honesty, which 
involves concealing the truth or failing to say and do the right thing.

Honesty is a Qur'anic and Sunnahbased Islamic obligation. Other religions' teachings in Indonesia also show honesty. In social situations, honesty is also essential for forming interpersonal relationships and extending social interaction networks. Academics, business, politics, law, and everyday life all require honesty. However, in today's world, honesty comes at a high price.

Honesty is an important aspect of one's psychological personality. The five leading personalities (Sorić et al., 2017) were the most well-known personality descriptions from 1980 to the early twentieth century. These five variables were crucial in describing the average difference between participants. The query thus appears to be an unfinished statement from one of the Big
Five, notably, honesty (Cervone \& Pervin, L, 2015). As a result, honesty is referred to as the sixth personality trait (honesty is the sixth personality trait) (Guo et al., 2019).

There are numerous assumptions concerning the importance of honesty from a psychological standpoint. As psychologists and founders of positive psychology, Seligman and Peterson feel that honesty encompasses more than just technical significance. Honesty, as well as how people control their emotions and sustain what they do to achieve their expectations, are all character strengths (Staats et al., 2008).

Suud \& Subandi (2017) did a bibliographic and empirical study on honesty and came up with the following findings:

\begin{tabular}{|l|ll|}
\hline \multicolumn{1}{|c|}{ Literature Research (PN-1) } & \multicolumn{1}{c|}{ Empirical Research (PN-2) } \\
\hline $\begin{array}{l}\text { 1. Laws that match reality } \\
\text { 2. Expressions that match the heart }\end{array}$ & $\begin{array}{l}\text { 1. The similarity between what is in the } \\
\text { heart, in speech, and action. }\end{array}$ \\
$\begin{array}{l}\text { 3. Words or actions and true conscience or } \\
\text { feelings that are following reality as it is. }\end{array}$ & $\begin{array}{l}\text { 2. Harmony between words, actions, and } \\
\text { feelings }\end{array}$ \\
$\begin{array}{l}\text { 4. Honest in speech, in intentions and } \\
\text { intentions, in determination, in holding } \\
\text { beliefs, inactions, and honesty in }\end{array}$ & $\begin{array}{l}\text { 3. Harmony between expressions, data, and } \\
\text { facts. }\end{array}$ \\
$\begin{array}{l}\text { realizing all religious teachings. } \\
\text { Conformity between actions and beliefs }\end{array}$ & $\begin{array}{l}\text { 4. Do not lie; speak according to facts and } \\
\text { reality. }\end{array}$ \\
& $\begin{array}{l}\text { Obligations and principles must be } \\
\text { carried out to achieve the level of purity } \\
\text { and to achieve the goodness of life. }\end{array}$ \\
\hline
\end{tabular}

From the perspective of the Qur'an, Quraish Shihab (Suud, M et al., 2020) defines honesty as a person who has a specific understanding, is always correct, and is honest. They've never been tainted by sin, but they've never broken any rules (Shihab, 1996). As seen in Surah al-Ahzab Chapter 8, honest people can refer others to ask questions, according to Shihab. Fourth, people who keep their promises to God determine the honesty of faith. Surah al-
Ahzab, chapter 23, offers this explanation. Fifth, loyalty and honesty are related. In Surah Taubah verse 119 and verse 33 of AzZumar Al-Qur'an, Allah says that honesty and righteousness are related.

Everyone relied upon Prophet Muhammad because of his honesty in all things, not only Muslims but also nonMuslims. He even trained with the enemy openly and transparently. As a response, the Prophet's name was changed to al-Amin 
(Amanah). Muslims must believe that the Prophet Muhammad is Siddiq, which means king, one of his characteristics. Honesty, according to the Prophet, might make people great.

The authors conclude that honesty education for children is moral character education, which aims to teach children aged 0 to 6 years to live in harmony, based on the above study of early childhood education, Islamic psychology, and honesty. Muslims follow the Qur'an and Hadith as their primary guide in their hearts, thoughts, words, and actions. The discussion as the following would be focused on how to apply this educational practice in early life from an Islamic point of view.

In his study of Islamic cognitive development and its effect on education, (Shehu, 2015) describes the stages of human growth from the first to the ninth stage. Two of the nine stages, according to the author, are related to early childhood, namely:

\section{The Sensory Perception Period is the first stage (From birth to 2 years)}

The earliest stage of life after birth. The five sense organs provide information to the mind at this stage, which is characterized by sense perception. The mind is empty or tabula rasa in the early stages of this stage, as can be concluded from Qur'anic passages that postulate this stage. Based on its limited experience and maturity, the mind then analyzes and retains information. At this age, conduct is primarily characterized by intrinsic reactive and instinctual tendencies (speciebehavior).

This inclination lessens over time as a result of frequent engagement with the environment and is eventually replaced by voluntary behavior. This stanza denotes a certain level of cognitive growth.

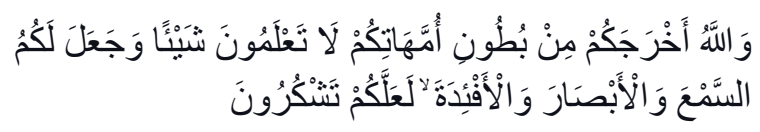

Meaning: And Allah brought you forth from the wombs of your mothers not knowing anything and $\mathrm{He}$ gave you the senses of hearing, seeing, and comprehending. It is hoped that you would be grateful (Q.S: AnNahl: 78).

\section{Stage Two: Early Childhood (From 2-7 years)}

Many verses convey this stage. For example, verse 5 of Surah An - Nisa:

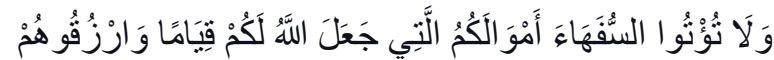

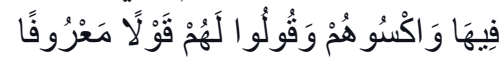

Meaning: And do not give the riotous your property, which Allah has made a means of sustenance for you, but provide for them with it and clothe them and speak to them with words of kindness. (Q.S. An-Nisa: 5)

The phrase "those who are weak in understanding" has also been interpreted by scholars such as Ibn Abbas. The

Hadith in which the Prophet (SAW) instructed that children as young as seven should be ordered to pray is the basis for determining the age limit going up from this stage at the age of seven (7) years. This Hadith shows whenever a child reaches seven, he has completed one stage of mental development and has moved to the next.

Early childhood education, according to (Rahmawati, 2019) of Imam Al Ghazali, who studies child development, can be divided into two stages: fetal and infant stages. The fetus is a condition that the child will experience in the next life. Parents are recommended to develop positive behaviors and maintain personal hygiene during pregnancy in support of the baby to remain in the womb in the future. Healthy and halal 
food, according to Al Ghazali, will also generate a healthy and halal fetus. Moreover, according to (Rahmawati, 2019), the role of parents in childhood is that of a model and role model; it is important to use methods that adapt to the child's abilities and allow him to play. On this basis, the study tries to characterize the stages of children's integrity education as obeys:

1. Conception Period, in this phase is the union of sperm and egg which will then occur in the process of fertilization and produce a fetus. Reading Basmalah, Al Ikhlas, Takbir, Altawhid, Tahlil, and other are also included in the phase, according to Al Ghazali, whom describes the correct procedure for intercourse according to the Prophet's Sunnah. As a result, it is clear that proper prayer, as an Islamic procedure, is supposed to create good children or progeny.

2. Children aged 0 to 3 years. As already noted, the child is very reliant on the stimulus of his environment during such a age; cognitively, he is like white paper. Considering Piaget's terms for good things, good and halal food, and creating an intense feel that truly becomes role models for children, a positive character or honesty can be installed into the schemata during such a phase.

3. Aged: 4-6 years. Children have started to form the environment to play and learn with others at this phase. The child has started to explore the environment outside and to get to know his friends. In this phase, it is important to ensure that children have a safe and stimulating environment to play in, and children aged 4-6 years have started to participate in what is called as early childhood education. According to the author, the essential aspect of early childhood honesty character education must be considered throughout this era.
According to (Heryadi \& Abd. Madjid, 2021) research, a model storyteller, a girl selling milk, stories from the era of Caliph Ummar Bin Khattab, and pottery can complete moral character education at the age of 46. Cups. Hadith collections are still a collection of hadith collections. (Ummi \& Martoni, 2020), (Adriani et al., 2021), (Agustina \& Kurniawan, 2019) Research, and (Ramdhani et al., 2019) all confirm this sort of moral character education in early childhood (2019). Ummi's research (2020) analyzes how the Apostle tale approach can help Sumenep children develop a more honest character, whereas Adriani et alresearch.'s (2021) investigates storytelling as a strategy for instilling honesty in children. In Pontianak, a 56-year-old boy. The relevance of narrative in character education is further explained in (Agustina \& Kurniawan, 2019) research. Storytelling, according to (Lestari, 2018), is an oral communication art that crosses time and culture and provides knowledge, information, recommendations, ideas, emotions, feelings, and understanding to others, especially adolescents and children. What stories will they tell and how will their personalities be influenced to become moral role models and follow?

\section{Conclusion}

From the perspective of Islamic psychology, this study attempts to answer research issues about what and how moral instruction for early childhood is provided. By making the Koran and Hadith the fundamental standards, you can harmonize what is in your heart, mind, and actions with words and actions that always speak according to facts. This research also aims to prioritize honesty teaching during the conception phase, ages 0 to 3, and ages 4-6. The important phase of honesty character education, according to the author, is between the ages of 4-6 years, and the narrative model 
can be used as a guide for this teaching. According to the author, the research's shortcoming is the method used, which is solely based on library research; an experiment is required to further test the notions presented. The author's recommendations for future research include looking into the following stages of human development, particularly from the ages of 7 to 24 , or until entering the early adult phase, to see how Islamic psychology can help with honesty character education and anticorruption education in general. What is the significance of this? Individuals have begun to interact with activities that require honesty and anti-corruption or non-corrupt behavior in working in various sectors starting at the age of 25 years or early adulthood, according to the author.

\section{References}

Shehu, S. (2015). A Study of the Islamic Adriani, F. V., Marmawi, R., \& Amalia, A. (2021). Strategi penanaman nilai kejujuran pada anak usia 5-6 tahun di tk negeri pembina pontianak barat. Jurnal Pendidiian Dan Pengajaran, 10(3), 1-9. https://jurnal.untan.ac.id/index.php/jpdpb /article/view/45626/75676588700

Agustina, F., \& Kurniawan, A. M. B. (2019). Penanaman Pendidikan Karakter dan Metode Story Telling. Jurnal Penelitian Medan Agama, 10(2), 256-280. http://jurnal.uinsu.ac.id/index.php/medag /article/view/6408

Aryani, S. . (2018). Psikologi Islami. In Psikologi Islami (Vol. 19, Issue Titik Singgung Antara Tasawuf, Psikologi, Agama dan Kesehatan Mental). Suka Press. http://digilib.uinsuka.ac.id/id/eprint/31576/2/Sekar Ayu Aryani - Psikologi Islami.pdf

Cervone, D., \& Pervin, L, A. (2015). Personality: Theory and Research, 13th Edition. John Wiley \& Sons.
Guo, Z. H., You, Z. H., Wang, Y. Bin, Yi, H. C., \& Chen, Z. H. (2019). A LearningBased Method for LncRNA-Disease Association Identification Combing Similarity Information and Rotation Forest. IScience, 19, 786-795. https://doi.org/10.1016/j.isci.2019.08.03 0

Heryadi, A., \& Abd. Madjid. (2021). Girl selling milk: storytelling of teaching the islamic honesty value 1. Proceeding IConIGC: International Conference on Islamic and Global Civilization, 2021, 63-70. http://conference.unisma.ac.id/index.php /iconigc/IConIGC/paper/view/1213

Heryadi, A., Evianawati, E., \& Atmaningrum, A. (2020). Where Anti-Corruption Education Need To Be Started. GUIDENA: Jurnal Ilmu Pendidikan, Psikologi, Bimbingan Dan Konseling, 10(2), https://doi.org/10.24127/gdn.v10i2.2771

Lestari, D. P. (2018). Peningkatan Perilaku Anti Korupsi Melalui Metode Story Telling. Raudhatul Athfal: Jurnal Pendidikan Islam Anak Usia Dini, 2(1), 95-105.

https://doi.org/10.19109/ra.v2i1.2238

Rahmawati, M. (2019). Mendidik Anak Usia Dini dengan Berlandaskan Pemikiran Tokoh Islam Al- Ghazali. Al Fitrah Journal Of Early Childhood Islamic Education, 2(2), 274-286. https://doi.org/10.29300/alfitrah.v2i2.22 71

Ramdhani, S., Yuliastri, N. A., Sari, S. D., \& Hasriah, S. (2019). Penanaman Nilainilai Karakter Melalui Kegiatan Storytelling dengan Menggunakan Cerita Rakyat Sasak pada Anak Usia Dini. Obsesi, 3(1), 153-160. https://doi.org/http://10.31004/obsesi/v3i 1.108

Saputra, A. (2018). Pendidikan Anak Pada 
Usia Dini. Jurnal Ilmiah Pendidikan Agama Islam, 10(2), 192-209. https://core.ac.uk/download/pdf/2288226 55.pdf

Shehu, S. (2015). A Study of the Islamic Perspective of Cognitive Development and Its Implications in Education in the Muslim World. Revelation and Science, 5(1), 1-9. https://doi.org/https://www.researchgate. net/publication/264043739_A_Study_of _the_Islamic_Perspective_of_Cognitive_ Development_Implications_to_Educatio n_in_the_Muslim_World

Shihab, Q. (1996). Wawasan Al-Quran. Mizan.

Sorić, I., Penezić, Z., \& Burić, I. (2017). The Big Five personality traits, goal orientations, and academic achievement. Learning and Individual Differences, 54, 126-134.

https://doi.org/https://doi.org/10.1016/j.li ndif.2017.01.024

Staats, S., Hupp, J, M., \& Wallace, H. (2008). Honesty and Heroes: A Positive Psychology View of Heroism and Academic Honesty. APA 116th Annual Convention, Boston, Massachusetts, 142, 357-372.

https://doi.org/https://doi.org/http://dx.do i.org/10.1037/e489002008-001

Subandi, M. A. (2010). Konsep Psikologi Islam Dalam Sastra Sufi. Millah, 10(1), 143-159.

https://doi.org/10.20885/millah.vol10.iss 1.art9

Suud, M, F., Sutrisno, \& Madjid, A. (2020). Honesty: A Multidimensional Study as Motivation for National Character Building. Hayula: Indonesian Journal of Multidisciplinary Islamic Studies, 4(1), 99-116. https://doi.org/10.21009/004.01.06

Suud, F. M., \& Subandi. (2017). Kejujuran dalam Perspektif Psikologi Islam: Kajian
Konsep dan Empiris. Jurnal Psikologi Islam, 4(2), 121-134. http://jpi.apihimpsi.org/index.php/jpi/article/view/44 Ummi, K., \& Martoni. (2020). Meningkatkan Karakter Jujur Anak Usia Dini Kelompok B Melalui Metode Cerita Para Rasul Di Ra Ruhul Islam Al-Muntaha Gapura Timur Gapura Sumenep Tahun Pelajaran 2018/2019. Jurnal Setia Pancasila, 1(1), 30-40. https://ejurnal.stkippgrisumenep.ac.id/index.php/ JSP/article/view/78

Zaharuddin, Z. (2017). Psikologi Islam Perspektif Malik Badri. Psikis: Jurnal Psikologi Islami, 3(1), 43. https://doi.org/10.19109/psikis.v3i1.1392 